\title{
Drug Therapies for the Management of Sickle Cell Disease
}

\section{[version 1; peer review: 2 approved]}

\author{
Parul Rai(iD), Kenneth I. Ataga(i)2 \\ ${ }^{1}$ Department of Hematology, St. Jude Children's Research Hospital, Memphis, TN, USA \\ ${ }^{2}$ Center for Sickle Cell Disease, University of Tennessee Health Science Center, Memphis, TN, USA
}

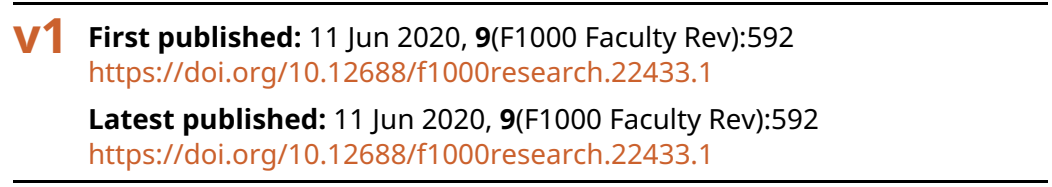

\section{Abstract}

Sickle cell disease (SCD) afflicts millions of people worldwide but is referred to as an orphan disease in the United States. Over the past several decades, there has been an increasing understanding of the pathophysiology of SCD and its complications. While most individuals with SCD in resource-rich countries survive into adulthood, the life expectancy of patients with SCD remains substantially shorter than for the general African-American population. SCD can be cured using hematopoietic stem cell transplantation and possibly gene therapy, but these treatment approaches are not available to most patients, the majority of whom reside in low- and middle-income countries. Until relatively recently, only one drug, hydroxyurea, was approved by the US Food and Drug Administration to ameliorate disease severity. Multiple other drugs (L-glutamine, crizanlizumab, and voxelotor) have recently been approved for the treatment of SCD, with several others at various stages of clinical testing. The availability of multiple agents to treat SCD raises questions related to the choice of appropriate drug therapy, combination of multiple agents, and affordability of recently approved products. The enthusiasm for new drug development provides opportunities to involve patients in low- and middle-income nations in the testing of potentially disease-modifying therapies and has the potential to contribute to capacity building in these environments. Demonstration that these agents, alone or in combination, can prevent or decrease end-organ damage would provide additional evidence for the role of drug therapies in improving outcomes in SCD.

\section{Keywords}

Sickle cell disease, Treatment, Novel Drugs, Drug Development, Clinical Trials

\section{Open Peer Review}

Approval Status

1 2

version 1

11 Jun 2020

Faculty Reviews are review articles written by the prestigious Members of Faculty Opinions. The articles are commissioned and peer reviewed before publication to ensure that the final, published version is comprehensive and accessible. The reviewers who approved the final version are listed with their names and affiliations.

1. Daniel E. Bauer, Boston Children's Hospital, Boston, USA

Dana-Farber Cancer Institute, Boston, USA

Harvard Medical School, Boston, USA

2. Yogen Saunthararajah, Taussig Cancer

Institute, Cleveland Clinic, Cleveland, USA

Any comments on the article can be found at the end of the article. 
Corresponding author: Kenneth I. Ataga (kataga@uthsc.edu)

Author roles: Rai P: Investigation, Writing - Original Draft Preparation; Ataga KI: Conceptualization, Supervision, Writing - Original Draft Preparation, Writing - Review \& Editing

Competing interests: KIA has served on clinical advisory boards and/or served as a consultant for Global Blood Therapeutics, Novartis, Emmaus Life Sciences, Editas Medicine, and Novo Nordisk. PR has no competing interests.

Grant information: This work is supported by an award from the US Food and Drug Administration - R01FD006030 (KIA).

The funders had no role in study design, data collection and analysis, decision to publish, or preparation of the manuscript.

Copyright: (c) 2020 Rai P and Ataga KI. This is an open access article distributed under the terms of the Creative Commons Attribution License, which permits unrestricted use, distribution, and reproduction in any medium, provided the original work is properly cited.

How to cite this article: Rai P and Ataga KI. Drug Therapies for the Management of Sickle Cell Disease [version 1; peer review: 2 approved] F1000Research 2020, 9(F1000 Faculty Rev):592 https://doi.org/10.12688/f1000research.22433.1

First published: 11 Jun 2020, 9(F1000 Faculty Rev):592 https://doi.org/10.12688/f1000research.22433.1 


\section{Introduction}

Although referred to as an orphan disease in the United States (US), sickle cell disease (SCD) affects millions of individuals worldwide, with the vast majority residing in sub-Saharan Africa and India ${ }^{1}$. SCD is characterized by the presence of sickle hemoglobin ( $\mathrm{HbS})$, hemolytic anemia, vaso-occlusive complications, and cumulative end-organ damage. The mortality rate associated with SCD in sub-Saharan Africa remains high, with an estimated 50 to $90 \%$ of children dying before the age of $5^{2}$. However, the majority of children with $\mathrm{SCD}$ in resource-rich countries live to adulthood ${ }^{3-5}$. Despite increased survival to adulthood, individuals with SCD in resource-rich nations continue to have a shorter life expectancy than the general population ${ }^{6-9}$. There has been substantial progress with the use of allogeneic bone marrow transplantation as a curative therapy in SCD, and increasing evidence supports the curative potential of gene therapy and gene editing ${ }^{10,11}$. However, as these modalities are not available to the vast majority of patients, most of whom reside in resourcelimited countries, the availability of drug therapies that are safe, effective, and affordable remains highly desirable.

This review will focus on approaches to develop drug therapies in SCD, ongoing and recently completed trials, and our perspective on the use of approved drugs.

\section{Pathophysiology}

The development of effective therapies for SCD depends on an adequate understanding of its pathophysiology. Although the pathophysiology of SCD is complex and involves multiple pathways, the primary event is due to the polymerization of $\mathrm{HbS}$ following deoxygenation ${ }^{12}$. The rate and extent of polymer formation depends on the degree and duration of $\mathrm{HbS}$ deoxygenation, presence of fetal hemoglobin $(\mathrm{HbF})$, and the intracellular concentration of $\mathrm{HbS}$. Clinical manifestations of SCD appear to be driven by two major pathophysiological processes: vaso-occlusion with ischemia-reperfusion injury and hemolytic anemia $^{13}$. Vaso-occlusion occurs because of adhesive interactions of leukocytes and sickle RBCs with the endothelium causing microvascular obstruction and subsequent tissue ischemia ${ }^{13}$. These episodes of vascular obstruction are followed by the restoration of blood flow, which promotes further tissue injury by reperfusion. The inflammatory cascade resulting from ischemiareperfusion is amplified by the activation of CD1d-restricted invariant natural killer $\mathrm{T}$ (iNKT) cells ${ }^{14}$. The release of free plasma hemoglobin following intravascular hemolysis results in direct scavenging of nitric oxide (NO), as well as the generation of reactive oxygen species, powerful scavengers of $\mathrm{NO}^{15,16}$. $\mathrm{NO}$ is usually produced by the endothelium and regulates basal vasodilator tone as well as inhibits the activation of platelets and the coagulation system and the transcriptional expression of nuclear factor $\kappa \mathrm{B}(\mathrm{NF} \kappa \mathrm{B})$-dependent adhesion molecules, such as vascular cell-adhesion molecule-1, intercellular cell-adhesion molecule-1, and selectins ${ }^{17,18}$. HbS polymerization as well as its multiple downstream consequences, including endothelial cell injury, endothelial dysfunction, increased oxidant stress, inflammation, and coagulation and platelet activation, are therapeutic targets in SCD (Figure 1). SCD has been dichotomized into two overlapping sub-phenotypes: viscosity-vaso-occlusion (higher hemoglobin levels, possibly increased blood viscosity, and complications such as osteonecrosis, acute chest syndrome, and acute pain crisis) and hemolysis-endothelial dysfunction (increased hemolysis with lower hemoglobin levels and higher levels of hemolytic markers, including reticulocyte

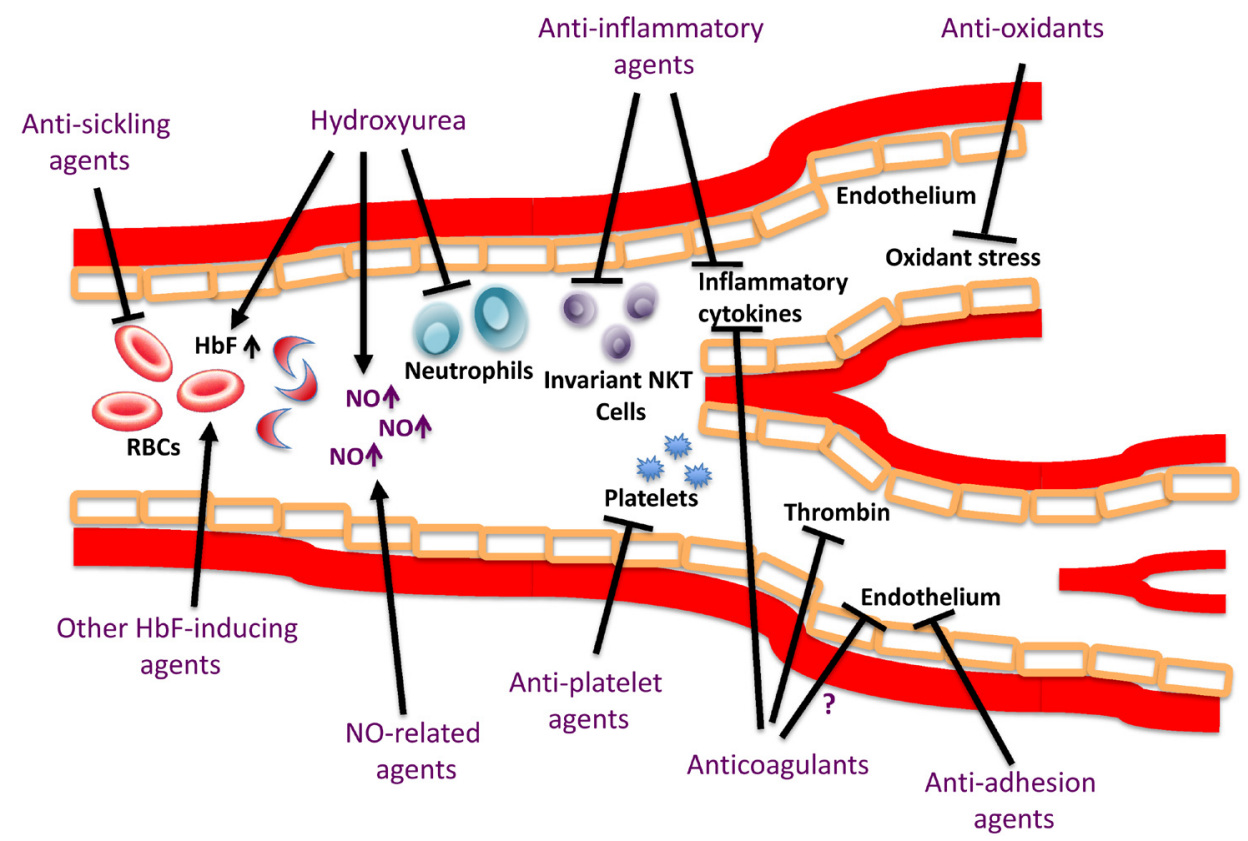

Figure 1. Potential targets of pharmacologic agents in sickle cell disease. HbF, hemoglobin F; NKT, natural killer T-cells; NO, nitric oxide; RBCs, red blood cells. Adapted with permission from Ataga KI and Stocker J. Br J Haematol, 2015. 
count and serum lactate dehydrogenase, and complications such as leg ulcers, priapism, stroke, and possibly pulmonary hypertension $)^{19}$. While somewhat simplistic, this classification is useful to understand the pathobiology of disease complications and may provide guidance on the effects of therapies on disease-related complications. The pathophysiology of SCD has been reviewed more extensively elsewhere ${ }^{20-22}$.

\section{Drug therapies for sickle cell disease}

Despite an improved understanding of the pathophysiology of SCD, available drug treatments remain limited. For many years, hydroxyurea was the only drug available to modify the severity of $\mathrm{SCD}^{23}$. However, there has been progress in the development of drug therapies with recent approvals of L-glutamine, crizanlizumab, and voxelotor by the US Food and Drug Administration (FDA $)^{24-26}$. Based on our current understanding of SCD pathophysiology, there are multiple possible approaches to treating the disease and its complications, including inhibition of $\mathrm{HbS}$ polymerization and amelioration of multiple downstream sequelae of $\mathrm{HbS}$ polymerization.

\section{Inhibition of sickle hemoglobin polymerization}

Therapeutic approaches targeting $\mathrm{HbS}$ polymerization, including 1) blocking intermolecular contacts in the sickle fiber, 2) induction of $\mathrm{HbF}$ synthesis, 3) reduction of intracellular $\mathrm{HbS}$ concentration, 4) increase in oxygen affinity, and 5) reduction of the concentration of 2,3-diphosphoglycerate, have been described $^{27}$. Table 1 lists ongoing studies of anti-sickling agents in SCD.

Induction of fetal hemoglobin. High levels of $\mathrm{HbF}$ ameliorate the severity of $\mathrm{SCD}^{8,28,29}$. Hydroxyurea strongly induces $\mathrm{HbF}^{30}$, although the mechanisms by which it does so are still unclear $^{30-33}$. Hydroxyurea improves erythrocyte deformability, lowers hemolysis, decreases circulating leukocytes and reticulocytes $^{34}$, reduces adhesion receptor expression ${ }^{35-38}$, and is an NO donor ${ }^{39,40}$. In two placebo-controlled, phase III trials, hydroxyurea significantly reduced the frequency of vasoocclusive crises, acute chest syndrome, blood transfusion requirement, and hospitalizations in adults and children with $\mathrm{SCD}^{23,41}$. Treatment with low, fixed weight-based dosing of hydroxyurea $(10 \mathrm{mg} / \mathrm{kg}$ daily) also decreased the frequency of SCD-related complications with low toxicity ${ }^{42,43}$. Hydroxyurea further ameliorates SCD morbidity by decreasing the risk of stroke and chronic kidney disease ${ }^{44,45}$ and may reduce mortality in $\mathrm{SCD}^{46-49}$. Recent studies to optimize hydroxyurea therapy are exploring dose maximization via pharmacokinetics-based dosing ${ }^{50-54}$. Despite its multiple benefits, a substantial number of patients on hydroxyurea may not obtain an adequate clinical response.

Inhibitors of epigenetic enzymes which repress $\gamma$-globin genes, including DNA methyltransferase (DNMT1), histone deacetylases, and lysine-specific demethylase (LSD-1), and $\gamma$-globin gene co-activator agonists are being evaluated in SCD. Decitabine (5-aza-2'-deoxycytidine), a DNA hypomethylating agent which depletes DNMT1, increased $\mathrm{HbF}$ and total hemoglobin levels at non-cytotoxic doses in patients who had no responses to hydroxyurea ${ }^{55}$. However, it has a very short plasma half-life and negligible oral bioavailability due to rapid inactivation by cytidine deaminase $(\mathrm{CDA})^{55}$. The combination of escalating doses of oral decitabine and an oral CDA inhibitor, tetrahydrouridine (THU), was well tolerated, and the highest tested dose increased $\mathrm{HbF}$, doubled F-cells by approximately $80 \%$ of total RBCs, increased total hemoglobin, and decreased biomarkers of hemolysis, coagulation activation, and inflammation ${ }^{56}$.

Histone deacetylase (HDAC) inhibitors increase $\mathrm{HbF}$ levels ${ }^{57-63}$. Although treatment with intermittent doses of sodium butyrate produced sustained increases in $\mathrm{HbF}$, F-cells, and total hemoglobin ${ }^{57}$, the orally available sodium dimethyl butyrate (HQK-1001) did not significantly increase $\mathrm{HbF}$ and appeared to result in more pain crisis compared with placebo ${ }^{63}$. A phase II study of the global HDAC inhibitor vorinostat was terminated early owing to poor accrual. Selective HDAC1/2 inhibition with ACY-957 increased $\mathrm{HbF}$ in vitro and represents a promising therapeutic approach with a better safety profile ${ }^{64}$. Based on the success of the LSD-1 inhibitors RN-1 and ORY-3001 in increasing $\mathrm{HbF}$ and F-cells in preclinical studies ${ }^{65-67}$, INCB059872 was investigated (NCT03132324). However, this phase I study was terminated early for business reasons. Pomalidomide, a third-generation immunomodulatory drug, produced modest increases of $\mathrm{HbF}$, augmented erythropoiesis, and preserved bone marrow function following 8 weeks of treatment in transgenic sickle mice ${ }^{68}$. Pomalidomide appeared to increase $\mathrm{HbF}$ and total hemoglobin only at the highest dose or with greater than 6 months of exposure ${ }^{69}$. The safety and efficacy of increasing the expression of $\gamma$-globin gene co-activators-FOXO3 agonist $^{70}$ (metformin [NCT02983129]), nuclear factor-like 2 (Nrf2) agonist $^{71}$ (dimethyl fumarate), and SIRT1 ${ }^{72}$ - to augment $\mathrm{HbF}$ levels are being explored.

Allosteric modification of sickle hemoglobin to its high-oxygen affinity $\boldsymbol{R}$-state. Voxelotor, recently approved under the FDA's accelerated approval program, is an orally bioavailable small molecule which binds to $\alpha$-globin chains of hemoglobin, increases hemoglobin oxygen affinity, and stabilizes the oxyhemoglobin state ${ }^{73}$. Early studies showed a reduction in markers of hemolysis, with a rapid rise in hemoglobin by day $15^{74}$. This response was not accompanied by worsening tissue hypoxia, based on serum erythropoietin levels and change in oxygen consumption $\left(\mathrm{VO}_{2} \max \right)$, even in participants receiving daily doses of $1,000 \mathrm{mg}$ for 28 days and $900 \mathrm{mg}$ for at least 90 days. Furthermore, voxelotor has been shown to reduce blood viscosity in vitro ${ }^{75}$. In a multicenter, phase III study of patients 12 to 65 years of age, randomly assigned to oncedaily oral voxelotor doses of $1,500 \mathrm{mg}, 900 \mathrm{mg}$, or placebo, a significantly higher percentage of subjects on $1,500 \mathrm{mg}$ had a hemoglobin response of $1.0 \mathrm{~g} / \mathrm{dL}$ at 24 weeks compared with placebo $^{76}$. In addition, subjects on the $1,500 \mathrm{mg}$ dose saw significant reductions in indirect bilirubin and reticulocyte counts from baseline. A dose-dependent increase in hemoglobin following treatment with voxelotor was not accompanied by an increase in pain crisis rate. As this trial was not enriched for subjects with frequent pain crises, appropriately designed studies 


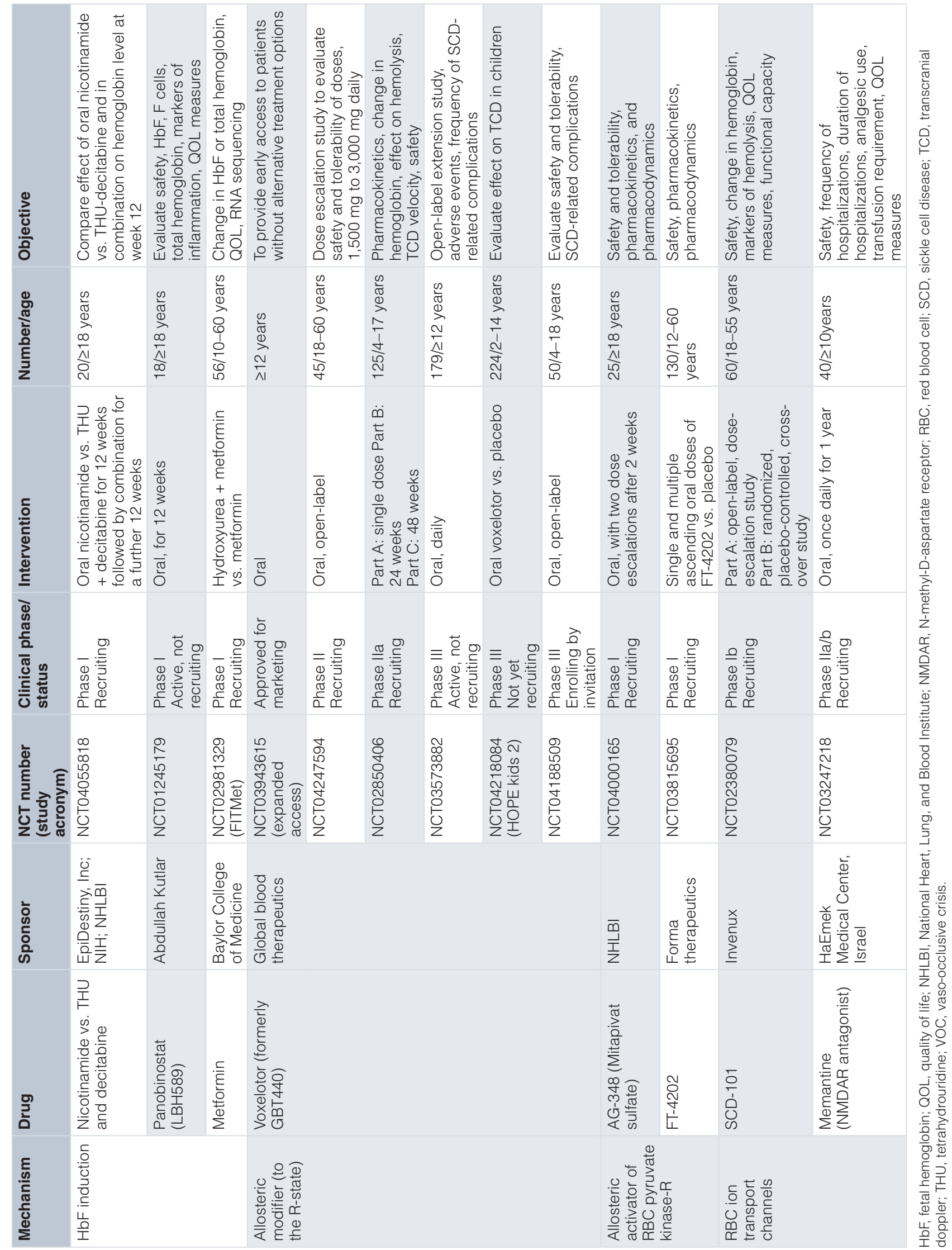


of patients with frequent pain episodes are needed to determine the effect of voxelotor on reducing such crises. Open-label extension studies to assess the long-term effects of voxelotor are ongoing.

5-hydroxymethyl-2-furfural (5HMF, Aes-103) interacts allosterically with $\mathrm{HbS}$, increasing oxygen affinity and decreasing $\mathrm{HbS}$ polymerization and RBC sickling during hypoxia. A phase I trial, with oral doses of up to $4,000 \mathrm{mg}$, showed no significant side effects ${ }^{77}$, but a phase II trial was terminated early because of unblinding of drug groups (NCT01987908). FT-4202, a novel selective activator of RBC pyruvate kinase, decreases intracellular 2,3-diphosphoglycerate levels, with a resulting increase in hemoglobin-oxygen affinity. It demonstrated a favorable safety profile in healthy individuals ${ }^{78}$ and is being investigated in a phase I study in SCD (NCT03815695).

The oxygen delivery therapeutic agents sanguinate (pegylated bovine carboxyhemoglobin) and MP4CO (pegylated human carboxyhemoglobin) are dual transfer agents which release carbon monoxide when delivering oxygen to hypoxic tissues. They stabilize $\mathrm{HbS}$ in its R-state and appear to exhibit anti-inflammatory and anti-apoptotic activity by induction of Nrf2 and heme oxygenase- $1^{79,80}$. Sanguinate had an acceptable safety profile $^{81,82}$. A phase II study evaluating its efficacy during acute pain crisis was recently completed (NCT02411708).

Increase red blood cell hydration. The inverse relationship between $\mathrm{HbS}$ concentration and delay time suggests that even small decreases in intracellular $\mathrm{HbS}$ might be beneficial ${ }^{83}$. Senicapoc selectively blocks the calcium-activated, potassium efflux (Gardos) channel and improves anemia and hemolysis in $\mathrm{SCD}^{84,85}$. Despite improvements in anemia and hemolysis, a phase III trial showed no significant decrease in the rate of pain crises compared to placebo $^{84}$. Similarly, studies of agents that block the potassium-chloride co-transport channel showed no clinical benefits ${ }^{86-88}$. SCD101, a botanical drug with an unclear anti-sickling mechanism which might involve dilution of $\mathrm{HbS}$ by affecting the RBC membrane, was well tolerated in a phase Ib study, with a decrease in chronic pain and fatigue and improvement in leg ulcers ${ }^{89}$.

\section{Targeting downstream sequelae of sickle hemoglobin polymerization}

Antioxidant therapy. Agents that upregulate antioxidant and/or reactive oxygen species scavenging processes have been evaluated in SCD. Glutamine, a conditionally essential amino acid, is a precursor for nicotinamide adenine dinucleotide (NAD) and improves NAD redox potential. In a randomized, multicenter trial of 230 patients with $\mathrm{HbSS}$ or $\mathrm{HbS}^{\circ}$-thalassemia, L-glutamine significantly reduced the number of pain crises, hospitalizations, cumulative hospital days, and frequency of acute chest syndrome compared with placebo $^{90}$. However, the effect size of L-glutamine in reducing pain crises was relatively small, with only a $25 \%$ reduction in the median number of pain crises. L-glutamine was well tolerated, although low-grade nausea, non-cardiac chest pain, fatigue, and musculoskeletal pain occurred more frequently than with placebo. Despite some concerns related to the high dropout rate in the trial $(36 \%$
L-glutamine arm; $24 \%$ placebo arm), L-glutamine was approved by the FDA to reduce the acute complications of SCD in patients 5 years and older ${ }^{24}$.

In an open-label pilot trial of oral $\mathrm{N}$-acetylcysteine (NAC), treatment with either $1,200 \mathrm{mg}$ or $2,400 \mathrm{mg}$ daily for 6 weeks increased whole blood glutathione levels and decreased erythrocyte outer membrane phosphatidylserine exposure, plasma levels of advanced glycation products, and cell-free hemoglobin in both groups ${ }^{91}$. A randomized, placebo-controlled, double-blind trial of NAC at $600 \mathrm{mg}$ twice daily for 6 months did not decrease the rate of SCD-related pain days per patient year, vaso-occlusive crises, hospital admission days, number of admissions, or days with home analgesic use compared with placebo $^{92}$. The safety and efficacy of NAC, administered at a higher dose during pain crisis, is being explored in a phase I/II study (NCT01800526) (Table 2).

Anti-adhesive therapy. Agents targeting adhesion of blood cells to the endothelium have been investigated in SCD. Crizanlizumab, a humanized monoclonal anti-P-selectin antibody, was recently approved for use in patients 16 years and older for the prevention of vaso-occlusive crises $^{25}$ based on results of a randomized, double-blind, phase II study which evaluated the benefit of $2.5 \mathrm{mg} / \mathrm{kg}$ or $5 \mathrm{mg} / \mathrm{kg}$ doses versus placebo. Significantly lower median crisis rate, longer median times to first and second crises, and lower median rate of uncomplicated crises per year were observed with high-dose crizanlizumab compared with placebo following a 52-week treatment period $^{93}$. Multiple other studies of crizanlizumab are ongoing (Table 2).

Purified poloxamer 188, a nonionic block copolymer surfactant with hemorheologic and antithrombotic properties, was previously shown to significantly decrease the duration of pain episodes, especially in children and patients on hydroxyurea ${ }^{94}$. However, a more recent phase III study in children and adults reported no significant effect of purified poloxamer 188 (vepoloxamer or MST-188) on duration of vaso-occlusive crises compared with placebo $^{95}$. Rivipansel sodium (formerly GMI-1070) is a small-molecule pan-selectin inhibitor that binds to E-, P-, and L-selectin ${ }^{96}$. In a randomized, double-blind, adaptive, phase II trial, treatment with rivipansel during pain crisis produced a significant reduction in the mean cumulative intravenous opioid analgesic use compared to placebo ${ }^{97}$. However, despite the promising phase II trial results, the recently completed multicenter phase III RESET trial failed to meet its primary (time to readiness for discharge) and key secondary (time to discharge, cumulative intravenous opioid utilization, and time to discontinuation of intravenous opioids) efficacy endpoints ${ }^{98}$.

Heparins inhibit adhesive interactions via P-selectin ${ }^{99,100 .}$ Tinzaparin, a low-molecular-weight (LMW) heparin, at therapeutic dose reportedly decreased the number of hospital days, the number of days with pain crisis, and the number of days with the most severe pain scores compared with placebo $^{101}$. Sevuparin, a derivative of LMW heparin, which retains the P-selectin-binding domain of heparin but largely lacks anticoagulant properties, binds to $\mathrm{P}-$ and L-selectins, 


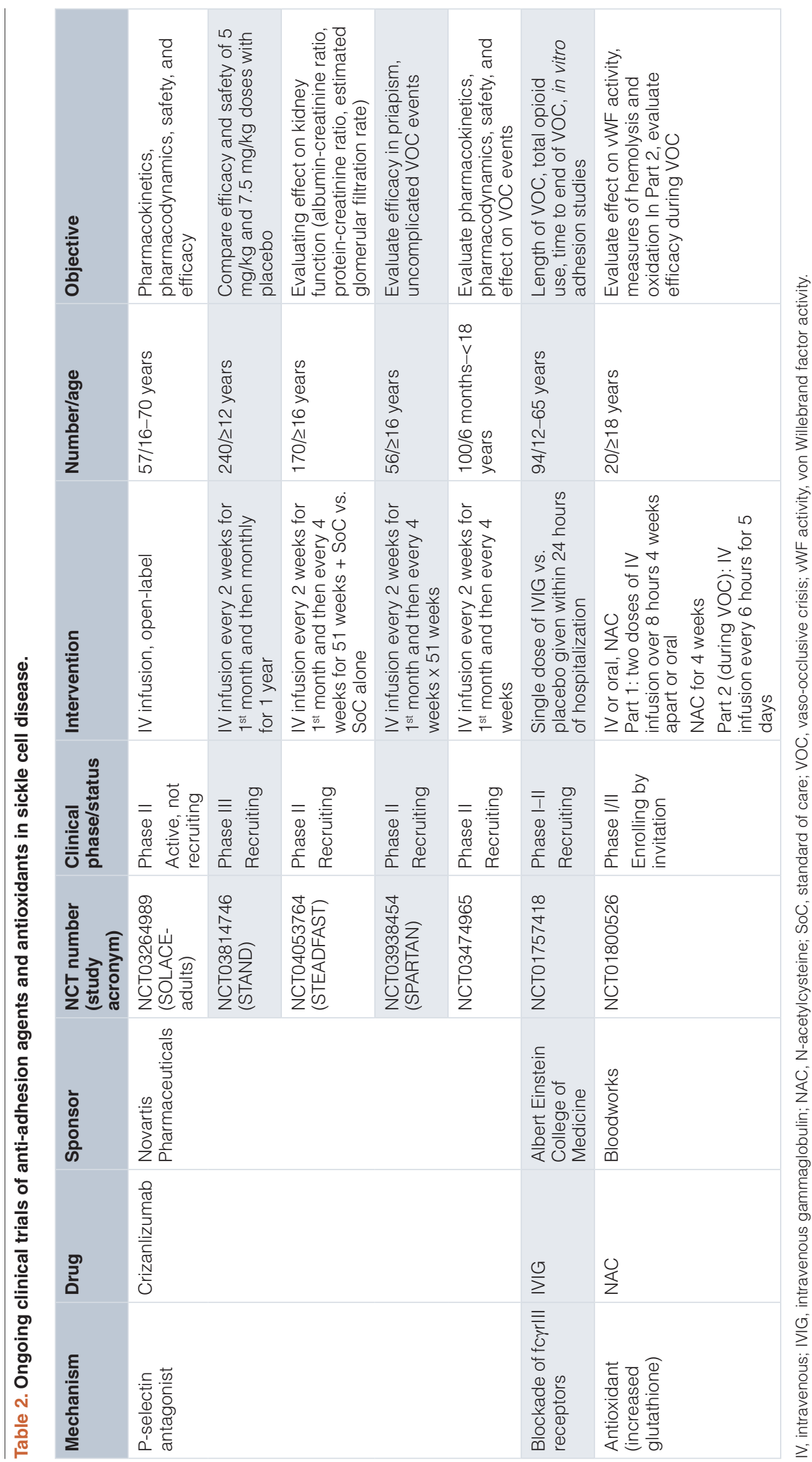


thrombospondin, fibronectin, and von Willebrand factor, inhibits the adhesion of sickle RBCs to stimulated cultured endothelial cells in vitro, and prevents vaso-occlusion with normalization of blood flow in a mouse model of vaso-occlusion ${ }^{102}$. A recently completed randomized, double-blind, placebo-controlled trial found that, although safe, sevuparin did not significantly reduce the time to resolution of vaso-occlusive crisis ${ }^{103}$. A phase II feasibility study of therapeutic-dose unfractionated heparin (NCT02098993) was recently terminated for poor enrollment, but a phase III, randomized, placebo-controlled study of tinzaparin in acute chest syndrome is ongoing (NCT02580773).

Intravenous immunoglobulin (IVIG) binds to FcyRIII receptors, inhibits neutrophil adhesion to the endothelium, reduces $\mathrm{RBC}$ capture by leukocytes, and reduces Mac-1 activity due to recruitment of Src homology 2-containing tyrosine phosphatase- $1^{104}$. IVIG was tolerated at doses of up to $800 \mathrm{mg} / \mathrm{kg}$ during acute vaso-occlusive crises and decreased Mac-1 function from baseline ${ }^{105}$. A phase II clinical trial of IVIG during acute pain episodes is ongoing (NCT01757418).

Anti-inflammatory agents. Multiple approaches to downregulate inflammatory pathways have been evaluated. Initial clinical responses with the use of steroids for pain crisis and acute chest syndrome were followed by "rebound" pain episodes and re-admissions after treatment discontinuation ${ }^{106,107}$. Inhaled corticosteroids did not significantly reduce the morbidity of acute chest syndrome in a retrospective cohort study ${ }^{108}$, but inhaled mometasone significantly reduced daily pain diary scores and levels of soluble vascular adhesion molecule-1 over the 16-week treatment period in another single-center, placebo-controlled trial $^{109}$.

The activation of iNKT cells is downregulated by the activation of adenosine $\mathrm{A} 2 \mathrm{~A}$ receptors $\left(\mathrm{A}_{2 \mathrm{~A}} \mathrm{R}\right)^{110}$. Regadenoson, a partially selective $A_{2 A} R$ agonist, was reportedly safe but did not decrease length of hospital stay, total opioid use, or pain scores compared to placebo during pain crises $^{111,112}$. In addition, there were no significant differences between regadenoson and placebo regarding the number of patients exhibiting a greater than $30 \%$ reduction in activated iNKT cells. The anti-iNKT cell monoclonal antibody NKTT120 resulted in rapid, specific, and continuous iNKT cell depletion in a single-ascendingdose study ${ }^{113}$, but further studies are required to determine its long-term safety and efficacy.

Statins have benefits independent of their cholesterollowering effect. In a pilot study, simvastatin was well tolerated, increased levels of NO metabolites, and decreased C-reactive protein (CRP) and interleukin-6 levels ${ }^{114}$. Daily treatment with simvastatin for 3 months significantly reduced pain crises, oral analgesic use, and levels of high-sensitivity CRP, soluble E-selectin, soluble ICAM-1, soluble ICAM-3, and $\mathrm{VEGF}^{115}$, providing supporting data for conduct of a placebocontrolled trial. Atorvastatin was well tolerated in a pilot study but did not improve endothelial function or decrease albuminuria ${ }^{116}$.
Long-chain omega-3 polyunsaturated fatty acids such as eicosapentaenoic acid (EPA [n-3]) and docosahexaenoic acid (DHA [n-6]) provide benefit to individuals with chronic inflammatory disorders. In a randomized, single-center study, daily omega-3 administered in capsule form significantly lowered the occurrence of vaso-occlusive events, severe anemia, blood transfusion requirements, and school absence compared with placebo ${ }^{117}$. More recently, a randomized, placebo-controlled study of different doses of SC411, a novel DHA ethyl ester formulation with high DHA bioavailability, found it was well tolerated, with significant reductions in d-dimer and E-selectin and an increase in hemoglobin ${ }^{118}$. SC411 also significantly reduced electronic diary-recorded pain episodes, analgesic use at home, and days absent from school but did not significantly lower pain crises in the pooled active groups compared to placebo.

Preliminary results suggest that the monoclonal anti-IL1 $\beta$ antibody canakinumab (ACZ885) is well tolerated and not associated with major side effects in $\mathrm{SCD}^{119}$.

Anticoagulant and antiplatelet therapies. With abundant evidence that SCD is a hypercoagulable state ${ }^{21}$, combined with data that coagulation and platelet activation may play roles in disease pathophysiology ${ }^{120-124}$, multiple studies have evaluated the effects of anticoagulants and antiplatelet agents in SCD. Although treatment with the LMW heparin tinzaparin produced more rapid resolution of pain crisis and shorter duration of hospitalization than placebo ${ }^{101}$, it is uncertain whether the reported beneficial effects were a result of its anticoagulant or anti-adhesive effects. The results of a pilot study of the direct oral anticoagulant rivaroxaban in SCD are awaited (NCT02072668).

Multiple relatively small studies of aspirin have reported modest benefit at best ${ }^{125-127}$, although one study reported an increase in oxygen affinity, hemoglobin level, and RBC lifespan ${ }^{126}$. A pilot study of the glycoprotein IIb/IIIa inhibitor eptifibatide showed that it was safe during acute pain episodes but did not reduce the time to resolution of such episodes ${ }^{128}$. Ticlopidine, a P2Y ${ }_{12}$ ADP-receptor antagonist, reportedly decreased the number of pain episodes, mean duration of pain episodes, and severity of such episodes ${ }^{129}$. However, a more recent phase III trial of prasugrel, a newer generation $\mathrm{P}_{2} \mathrm{Y}_{12}$ receptor blocker, showed no significant reduction of the frequency of pain episodes in children with $\mathrm{SCD}^{130}$. Ticagrelor, a reversible $\mathrm{P}_{2} \mathrm{Y}_{12}$ receptor blocker, was well tolerated in children ${ }^{131}$ and young adults $^{132}$ but had no beneficial effects on pain. A phase III study to determine the efficacy of ticagrelor in reducing vaso-occlusive crises in children is ongoing ${ }^{133}$ (Table 3).

Nitric oxide and related agents. With the role of hemolysis in NO scavenging and subsequent endothelial dysfunction, NO and related agents may be beneficial in $\mathrm{SCD}^{134}$. Inhaled $\mathrm{NO}$ did not improve time to resolution of pain crisis, length of hospitalization, opioid usage, or rate of acute chest syndrome compared with placebo ${ }^{135}$. In another study, inhaled NO did not reduce the rate of treatment failure in adult patients with mild 


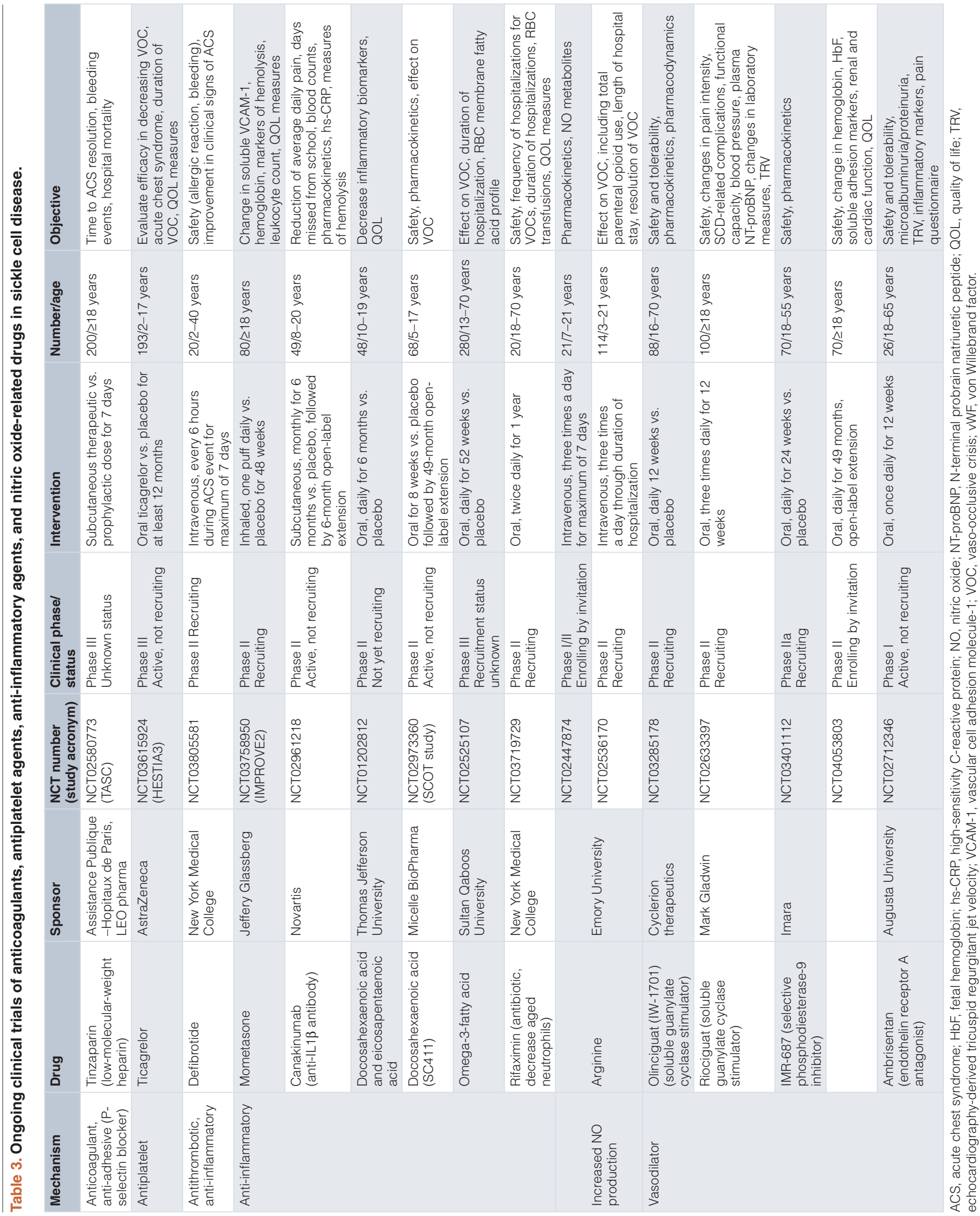


to moderate acute chest syndrome ${ }^{136}$. However, L-arginine, an NO precursor, significantly decreased total parenteral opioid use and pain scores at discharge compared to placebo in children, although there was no difference in length of hospital stay ${ }^{137}$. Furthermore, supplementation of adult patients on hydroxyurea with oral arginine significantly increased the level of NO metabolites and reduced the frequency of pain crises versus placebo following 4 months of treatment ${ }^{138}$. Sildenafil, a phosphodiesterase-5 inhibitor which increases NO-mediated effects by inhibiting the degradation of cyclic guanosine monophosphate (cGMP), was associated with more frequent serious adverse events, predominantly hospitalization for pain, compared with placebo $^{139}$. No evidence of a treatment effect of sildenafil was seen on evaluated study outcomes. Studies of soluble guanylate cycle stimulators, riociguat (NCT02633397) and olinciguat/IW-1701 (NCT03285178), and the phosphodiesterase-9 inhibitor IMR-687 (NCT03401112; NCT04053803) are ongoing (Table 3).

\section{Summary}

Recent advances in drug development for SCD raise important issues related to the use and availability of these agents. With limited availability of allogeneic bone marrow transplantation and gene therapy, especially in low- and middle-income countries, the number of recently approved drugs offers hope for further improved outcomes in SCD. Choice of initial drug therapy may be guided by a patient's clinical sub-phenotype as well as the cost of the drug (Table 4). Patients with frequent vaso-occlusive complications (acute pain episodes, acute chest syndrome) may benefit from hydroxyurea, L-glutamine, and crizanlizumab, while those with increased hemolytic anemia (or quite possibly complications related to hemolytic anemia) may benefit from

\section{Table 4. Summary characteristics of FDA-approved drugs for sickle cell disease.}

\begin{tabular}{|c|c|c|c|c|}
\hline & Hydroxyurea & L-Glutamine & Crizanlizumab & Voxelotor \\
\hline Age (years) & $\geq 2$ & $\geq 5$ & $\geq 16$ & $\geq 12$ \\
\hline Genotypes & $\mathrm{HbSS}, \mathrm{HbS} \beta^{0}$ thalassemia & $\begin{array}{l}\text { All genotypes (only } \\
\text { studied in HbSS, HbS } \beta^{\circ} \\
\text { thalassemia) }\end{array}$ & All genotypes & All genotypes \\
\hline Mechanism of action & $\begin{array}{l}\text { Multiple, but primarily by } \\
\text { increasing HbF production }\end{array}$ & $\begin{array}{l}\text { Uncertain, but thought } \\
\text { to reduce NAD redox } \\
\text { potential, possible } \\
\text { decrease in cell } \\
\text { adhesion }\end{array}$ & $\begin{array}{l}\text { Anti P-selectin inhibitor } \\
\text { (decreases adhesion } \\
\text { of WBCs and RBCs to } \\
\text { endothelium) }\end{array}$ & $\begin{array}{l}\text { Decreases HbS } \\
\text { polymerization by } \\
\text { increasing Hb-oxygen } \\
\text { affinity }\end{array}$ \\
\hline Route of administration & Oral (capsules/tablets) & Oral (powder) & Intravenous & Oral (tablets) \\
\hline $\begin{array}{l}\text { Clinical effects of } \\
\text { therapy }\end{array}$ & $\begin{array}{l}\text { Decreased frequency of VOC, } \\
\text { decreased frequency of ACS, } \\
\text { decreased hospitalization, } \\
\text { decreased RBC transfusion } \\
\text { requirement, decreased stroke risk }\end{array}$ & $\begin{array}{l}\text { Decreased frequency } \\
\text { of VOC, decreased } \\
\text { frequency of } \\
\text { ACS, decreased } \\
\text { hospitalization }\end{array}$ & $\begin{array}{l}\text { Decreased frequency } \\
\text { of VOC }\end{array}$ & Increased hemoglobin \\
\hline $\begin{array}{l}\text { Effect size for primary } \\
\text { endpoint ( } \% \text { change } \\
\text { and IRR) }\end{array}$ & $\begin{array}{l}\text { 44\% decrease in VOC per year } \\
\text { (median from } 4.5 \text { to } 2.5 \text { ), IRR = } \\
0.56\end{array}$ & $\begin{array}{l}25 \% \text { decrease in VOC in } \\
48 \text { weeks (median from } \\
4 \text { to } 3), I R R=0.75\end{array}$ & $\begin{array}{l}45 \% \text { decrease in crisis } \\
\text { rate per year (median } \\
\text { from } 3 \text { to } 1.6), I R R= \\
0.55\end{array}$ & $\begin{array}{l}5.5 \text {-fold increase in the } \\
\text { hemoglobin responders } \\
(9 \% \text { to } 59 \%) \text { at } 24 \\
\text { weeks, incidence } \\
\text { proportion ratio }=6.6^{\star}\end{array}$ \\
\hline Common toxicities & $\begin{array}{l}\text { Myelosuppression, skin } \\
\text { hyperpigmentation, nail } \\
\text { discoloration, teratogenicity, } \\
\text { decreased sperm counts, nausea } \\
\text { and vomiting }\end{array}$ & $\begin{array}{l}\text { Constipation, nausea, } \\
\text { headaches, abdominal } \\
\text { pain }\end{array}$ & Nausea, arthralgia & $\begin{array}{l}\text { Headache, diarrhea, } \\
\text { nausea }\end{array}$ \\
\hline Pharmacokinetics & $\begin{array}{l}\text { Excreted via kidneys Adjust dose } \\
\text { for eGFR }<60 \mathrm{~mL} / \mathrm{min} / 1.73 \mathrm{~m}^{2}\end{array}$ & $\begin{array}{l}\text { Use with caution with } \\
\text { hepatic and renal } \\
\text { impairment, but no } \\
\text { recommended dose } \\
\text { adjustment }\end{array}$ & $\begin{array}{l}\text { No dosage } \\
\text { adjustments in } \\
\text { manufacturer labeling } \\
\text { for renal and hepatic } \\
\text { impairment (not tested } \\
\text { in ESRD) }\end{array}$ & $\begin{array}{l}\text { No dosage adjustment } \\
\text { for renal impairment, } \\
\text { but not yet studied in } \\
\text { ESRD requiring dialysis } \\
\text { Dose reduction for } \\
\text { severe liver disease } \\
\text { (Child Pugh class C) }\end{array}$ \\
\hline Cost & $\$$ & $\$ \$ \$$ & $\$ \$ \$ \$ \$$ & $\$ \$ \$ \$ \$$ \\
\hline
\end{tabular}

ACS, acute chest syndrome; eGFR, estimated glomerular filtration rate; ESRD, end-stage renal disease; FDA, US Food and Drug Administration; Hb, hemoglobin; HbF, fetal hemoglobin; HbS, sickle hemoglobin; IRR, incidence rate ratio; NAD, nicotinamide adenine dinucleotide; RBC, red blood cell; VOC, vaso-occlusive crisis; WBC, white blood cell.

* Patients treated with 1,500 mg of voxelotor had 6.6 times increased proportion of hemoglobin responders (>1 g/dL increase from baseline at 24 weeks) 
hydroxyurea and voxelotor. However, more studies are required before definite recommendations can be made regarding the effect of voxelotor on SCD-related complications. As with other chronic disease conditions, it is important to consider the cost of the drug when deciding on initial therapy. Hydroxyurea is much cheaper than L-glutamine, crizanlizumab, and voxelotor and is likely more cost effective as initial therapy for vaso-occlusive complications and hemolytic anemia. However, with the complex pathophysiology of SCD and the limited clinical efficacy of available pharmacological therapies, it is unlikely that a single drug will ameliorate all SCD-related complications. As such, the availability of multiple drugs offers an opportunity for combination therapy based on different mechanisms of action and non-overlapping side effect profiles. Although more studies are required to evaluate the effect of combinations of these drugs, all of the recently approved agents were tested in combination with hydroxyurea. These studies showed benefit whether or not participants received concomitant hydroxyurea, with no increased toxicity. Despite potential benefits, combination therapy involving the use of multiple drugs increases the likelihood of decreased medication adherence owing to polypharmacy. Like in other chronic diseases, however, this problem may be somewhat ameliorated by the development of pills that contain more than one active drug.

It is particularly important that ongoing trials of novel drugs for SCD involve individuals in resource-limited countries where the burden of disease is high. This offers patients access to potentially disease-modifying therapies but, perhaps equally as important, contributes substantially to capacity building by improving local infrastructure, strengthening health systems, involving local leaders as collaborators, and training local providers. Furthermore, trials of novel agents in sub-Saharan Africa provide data on the effects of these therapies in a setting with fewer resources and unique challenges, including a high prevalence of malnutrition and infections such as malaria. With the high cost of recently approved agents, mechanisms to ensure affordable access to these drugs should be established. A situation where novel agents are tested in resource-limited countries but patients in these countries are unable to afford such drugs following approval is unacceptable. Finally, studies evaluating the effects of recently approved drugs on organ damage are needed. Demonstration that these agents prevent or decrease end-organ damage would provide additional evidence for the role of drug therapies in improving outcomes in SCD.

\section{Acknowledgements}

The authors thank Dr. Joacy Gerard Matthias and Dr. Matthew P. Smeltzer (Both from the Division of Epidemiology, Biostatistics, and Environmental Health, School of Public Health, University of Memphis, Memphis, Tennessee, USA) for helping to ascertain the drug effect sizes.
1. Piel FB, Hay SI, Gupta S, et al.: Global burden of sickle cell anaemia in children under five, 2010-2050: Modelling based on demographics, excess mortality, and interventions. PLoS Med. 2013; 10(7): e1001484. PubMed Abstract | Publisher Full Text | Free Full Text

2. Grosse SD, Odame I, Atrash HK, et al.: Sickle cell disease in Africa: A neglected cause of early childhood mortality. Am J Prev Med. 2011; 41(6 Suppl 4): S398-405.

PubMed Abstract | Publisher Full Text | Free Full Text

3. Telfer $\mathrm{P}$, Coen $\mathrm{P}$, Chakravorty $\mathrm{S}$, et al:: Clinical outcomes in children with sickle cell disease living in England: A neonatal cohort in East London. Haematologica. 2007; 92(7): 905-12. PubMed Abstract | Publisher Full Text

4. F Quinn CT, Rogers ZR, McCavit TL, et al:: Improved survival of children and adolescents with sickle cell disease. Blood. 2010; 115(17): 3447-52. PubMed Abstract | Publisher Full Text | Free Full Text | Faculty Opinions Recommendation

5. Couque N, Girard D, Ducrocq R, et al.: Improvement of medical care in a cohort of newborns with sickle-cell disease in North Paris: Impact of national guidelines. Br J Haematol. 2016; 173(6): 927-37. PubMed Abstract | Publisher Full Text

6. Elmariah H, Garrett ME, de Castro LM, et al.: Factors associated with survival in a contemporary adult sickle cell disease cohort. Am J Hematol. 2014; 89(5): $530-5$.

PubMed Abstract | Publisher Full Text | Free Full Text

7. Gardner K, Douiri A, Drasar E, et al:: Survival in adults with sickle cell disease in a high-income setting. Blood. 2016; 128(10): 1436-8. PubMed Abstract | Publisher Full Text

8. Maitra P, Caughey M, Robinson L, et al.: Risk factors for mortality in adult patients with sickle cell disease: A meta-analysis of studies in North America and Europe. Haematologica. 2017; 102(4): 626-36. PubMed Abstract | Publisher Full Text | Free Full Text

9. DeBaun MR, Ghafuri DL, Rodeghier M, et al.: Decreased median survival of adults with sickle cell disease after adjusting for left truncation bias: A pooled analysis. Blood. 2019; 133(6): 615-7. PubMed Abstract | Publisher Full Text | Free Full Text

10. Fitzhugh $\mathrm{CD}$, Abraham AA, Tisdale JF, et al.: Hematopoietic stem cell transplantation for patients with sickle cell disease: Progress and future directions. Hematol Oncol Clin of North Am. 2014; 28(6): 1171-85. PubMed Abstract | Publisher Full Text | Free Full Text

11. Ribeil JA, Hacein-Bey-Abina S, Payen E, et al.: Gene Therapy in a Patient with Sickle Cell Disease. N Engl J Med. 2017; 376(9): 848-55 PubMed Abstract | Publisher Full Text

12. Epstein FH, Bunn HF: Pathogenesis and Treatment of Sickle Cell Disease. $N$ Engl J Med. 1997; 337(11): 762-9. PubMed Abstract | Publisher Full Text

13. F Rees DC, Williams TN, Gladwin MT: Sickle-cell disease. Lancet. 2010; 376(9757): 2018-31.

PubMed Abstract | Publisher Full Text | Faculty Opinions Recommendation

14. Lawson V: Turned on by danger: Activation of CD1d-restricted invariant natural killer T cells. Immunology. 2012; 137(1): 20-7. PubMed Abstract | Publisher Full Text | Free Full Text

15. Reiter $\mathrm{CD}$, Wang $\mathrm{X}$, Tanus-Santos JE, et al:: Cell-free hemoglobin limits nitric oxide bioavailability in sickle-cell disease. Nat Med. 2002; 8(12): 1383-9. PubMed Abstract | Publisher Full Text

16. Repka T, Hebbel RP: Hydroxyl radical formation by sickle erythrocyte membranes: Role of pathologic iron deposits and cytoplasmic reducing agents. Blood. 1991; 78(10): 2753-8. PubMed Abstract | Publisher Full Text

17. de Caterina R, Libby P, Peng HB, et al:: Nitric oxide decreases cytokine-induced endothelial activation. Nitric oxide selectively reduces endothelial expression of adhesion molecules and proinflammatory cytokines. J Clin Invest. 1995; 96(1): 60-8. PubMed Abstract | Publisher Full Text | Free Full Text

18. Palmer RMJ, Ashton DS, Moncada S: Vascular endothelial cells synthesize nitric oxide from L-arginine. Nature. 1988; 333(6174): 664-6. PubMed Abstract | Publisher Full Text

19. Kato GJ, Gladwin MT, Steinberg MH: Deconstructing sickle cell disease: Reappraisal of the role of hemolysis in the development of clinical subphenotypes. Blood Rev. 2007; 21(1): 37-47. PubMed Abstract | Publisher Full Text | Free Full Text

20. Manwani D, Frenette PS: Vaso-occlusion in sickle cell disease: Pathophysiology and novel targeted therapies. Hematology Am Soc Hematol 
Educ Program. 2013; 2013: 362-9.

PubMed Abstract | Publisher Full Text

21. Noubouossie D, Key NS, Ataga KI: Coagulation Abnormalities of Sickle Cell Disease: Relationship With Clinical Outcomes and the Effect of Disease Modifying Therapies. Blood Rev. 2016; 30(4): 245-56.

PubMed Abstract | Publisher Full Text | Free Full Text

22. F Kato GJ, Piel FB, Reid CD, et al.: Sickle cell disease. Nat Rev Dis Primers. 2018; 4: 18010.

PubMed Abstract | Publisher Full Text | Faculty Opinions Recommendation

23. Charache $\mathrm{S}$, Terrin ML, Moore RD, et al.: Effect of hydroxyurea on the frequency of painful crises in sickle cell anemia. Investigators of the Multicenter Study of Hydroxyurea in Sickle Cell Anemia. N Engl J Med. 1995; 332(20): 1317-22. PubMed Abstract | Publisher Full Text

24. https://www.fda.gov/drugs/resources-information-approved-drugs/fda-disco-Iglutamine-sickle-cell-disease

25. https://www.novartis.com/news/media-releases/new-novartis-medicineadakveo-crizanlizumab-approved-fda-reduce-frequency-pain-crisesindividuals-living-sickle-cell-disease

26. https://www.fda.gov/drugs/resources-information-approved-drugs/fdaapproves-voxelotor-sickle-cell-disease

27. Eaton WA, Bunn HF: Treating sickle cell disease by targeting $\mathrm{HbS}$ polymerization. Blood. 2017; 129(20): 2719-26.

PubMed Abstract | Publisher Full Text | Free Full Text

28. Platt OS, Brambilla DJ, Rosse WF, et al:: Mortality in Sickle Cell Disease. Life Expectancy and Risk Factors for Early Death. N Engl J Med. 1994; 330(23): 1639-44.

PubMed Abstract | Publisher Full Text

29. Castro O, Brambilla DJ, Thorington B, et al.: The acute chest syndrome in sickle cell disease: Incidence and risk factors. The Cooperative Study of Sickle Cell Disease. Blood. 1994; 84(2): 643-9.

PubMed Abstract

30. Mabaera R, West RJ, Conine SJ, et al:: A Cell Stress Signaling Model of Fetal Hemoglobin Induction: What Doesn't Kill Red Blood Cells May Make Them Stronger. Exp Hematol. 2008; 36(9): 1057-72. PubMed Abstract | Publisher Full Text

31. Alcaín FJ, Löw H, Crane FL, et al:: Iron chelators hydroxyurea and bathophenanthroline disulfonate inhibit DNA synthesis by different pathways. Biochem Mol Biol Int. 1994; 34(2): 273-9.

PubMed Abstract

32. Cokic VP, Smith RD, Beleslin-Cokic BB, et al:: Hydroxyurea induces fetal hemoglobin by the nitric oxide-dependent activation of soluble guanylyl cyclase. J Clin Invest. 2003; 111(2): 231-9.

PubMed Abstract | Publisher Full Text | Free Full Text

33. Huang J, Yakubu M, Kim-Shapiro DB, et al:: Rat liver-mediated metabolism of hydroxyurea to nitric oxide. Free Radic Biol Med. 2006; 40(9): 1675-81. PubMed Abstract | Publisher Full Text

34. McGann PT, Ware RE: Hydroxyurea for sickle cell anemia: What have we learned and what questions still remain? Curr Opin Hematol. 2011; 18(3): 15865.

PubMed Abstract | Publisher Full Text | Free Full Text

35. Bridges KR, Barabino GD, Brugnara $C$, et al.: A multiparameter analysis of sickle erythrocytes in patients undergoing hydroxyurea therapy. Blood. 1996; 88(12): 4701-10.

PubMed Abstract

36. Hillery CA, Du MC, Wang WC, et al:: Hydroxyurea therapy decreases the in vitro adhesion of sickle erythrocytes to thrombospondin and laminin. $\mathrm{Br} J$ Haematol. 2000; 109(2): 322-7.

PubMed Abstract | Publisher Full Text

37. Odievre $\mathrm{MH}$, Bony $\mathrm{V}$, Benkerrou $\mathrm{M}$, et al:: Modulation of erythroid adhesion receptor expression by hydroxyurea in children with sickle cell disease. Haematologica. 2008; 93(4): 502-10.

PubMed Abstract | Publisher Full Tex

38. Laurance S, Lansiaux P, Pellay FX, et al:: Differential modulation of adhesion molecule expression by hydroxycarbamide in human endothelial cells from the micro- and macrocirculation: Potential implications in sickle cell disease vasoocclusive events. Haematologica. 2011; 96(4): 534-42. PubMed Abstract | Publisher Full Text | Free Full Text

39. Gladwin MT, Shelhamer JH, Ognibene FP, et al: Nitric oxide donor properties of hydroxyurea in patients with sickle cell disease. Br J Haematol. 2002; 116(2): $436-44$.

PubMed Abstract | Publisher Full Text

40. Glover RE, Ivy ED, Orringer EP, et al:: Detection of nitrosyl hemoglobin in venous blood in the treatment of sickle cell anemia with hydroxyurea. $\mathrm{MO}$ Pharmacol. 1999; 55(6): 1006-10. PubMed Abstract | Publisher Full Text

41. F Wang WC, Ware RE, Miller ST, et al.: Hydroxycarbamide in Very Young Children With Sickle-Cell Anaemia: A Multicentre, Randomised, Controlled Trial (BABY HUG). Lancet. 2011; 377(9778): 1663-72.

PubMed Abstract | Publisher Full Text | Free Full Text |

Faculty Opinions Recommendation

42. Dehury $S$, Purohit $P$, Patel $S$, et al.: Low and Fixed Dose of Hydroxyurea Is Effective and Safe in Patients With HbS $\beta(+)$ Thalassemia With IVS1-5(G $\rightarrow$ C)
Mutation. Pediatr Blood Cancer. 2015; 62(6): 1017-23.

PubMed Abstract | Publisher Full Text

43. Jain DL, Apte M, Colah R, et al:: Efficacy of Fixed Low Dose Hydroxyurea in Indian Children With Sickle Cell Anemia: A Single Centre Experience. India Pediatr. 2013; 50(10): 929-33.

PubMed Abstract | Publisher Full Tex

44. F Ware RE, Davis BR, Schultz WH, et al:: Hydroxycarbamide Versus Chronic Transfusion for Maintenance of Transcranial Doppler Flow Velocities in Children With Sickle Cell anaemia-TCD With Transfusions Changing to Hydroxyurea (TWiTCH): A Multicentre, Open-Label, Phase 3, Non-Inferiority Trial. Lancet. 2016; 387(10019): 661-70. PubMed Abstract | Publisher Full Text | Free Full Text | Faculty Opinions Recommendation

45. Bartolucci P, Habibi A, Stehlé T, et al:: Six Months of Hydroxyurea Reduces Albuminuria in Patients With Sickle Cell Disease. J Am Soc Nephrol. 2016 27(6): 1847-53

PubMed Abstract | Publisher Full Text | Free Full Text

46. Lobo CLdC, Pinto JFC, Nascimento EM, et al:: The Effect of Hydroxcarbamide Therapy on Survival of Children With Sickle Cell Disease. Br J Haematol. 2013; 161(6): 852-60.

PubMed Abstract | Publisher Full Text

47. Steinberg MH, Barton F, Castro O, et al.: Effect of Hydroxyurea on Mortality and Morbidity in Adult Sickle Cell Anemia: Risks and Benefits Up to 9 Years of Treatment. JAMA. 2003; 289(13): 1645-51.

PubMed Abstract | Publisher Full Text

48. F Steinberg MH, McCarthy WF, Castro O, et al:: The Risks and Benefits of Long-Term Use of Hydroxyurea in Sickle Cell Anemia: A 17.5 Year Follow-Up. Am J Hematol. 2010; 85(6): 403-8.

PubMed Abstract | Publisher Full Text | Free Full Text | Faculty Opinions Recommendation

49. F Voskaridou E, Christoulas D, Bilalis A, et al.: The Effect of Prolonged Administration of Hydroxyurea on Morbidity and Mortality in Adult Patients With Sickle Cell Syndromes: Results of a 17-year, Single-Center Trial (LaSHS). Blood. 2010; 115(12): 2354-63.

PubMed Abstract | Publisher Full Text | Faculty Opinions Recommendation

50. F Ware RE: Optimizing Hydroxyurea Therapy for Sickle Cell Anemia. Hematology Am Soc Hematol Educ Program. 2015; 2015: 436-43. PubMed Abstract | Publisher Full Text | Faculty Opinions Recommendation

51. F McGann PT, Niss O, Dong M, et al:: Robust clinical and laboratory response to hydroxyurea using pharmacokinetically guided dosing for young children with sickle cell anemia. Am J Hematol. 2019; 94(8): 871-9. PubMed Abstract | Publisher Full Text | Free Full Text | Faculty Opinions Recommendation

52. Estepp JH, Smeltzer MP, Kang G, et al:: A clinically meaningful fetal hemoglobin threshold for children with sickle cell anemia during hydroxyurea therapy. $\mathrm{Am}$ J Hematol. 2017; 92(12): 1333-9.

PubMed Abstract | Publisher Full Text | Free Full Text

53. Hydroxyurea Optimization Through Precision Study (HOPS). Clinical Trials. 2020

Reference Source

54. F Nazon C, Sabo AN, Becker G, et al:: Optimizing Hydroxyurea Treatment for Sickle Cell Disease Patients: The Pharmacokinetic Approach. J Clin Med. 2019; 8(10): 1701 .

PubMed Abstract | Publisher Full Text | Free Full Text |

Faculty Opinions Recommendation

55. Saunthararajah $\mathrm{Y}$, Molokie R, Saraf $\mathrm{S}$, et al:: Clinical effectiveness of decitabine in severe sickle cell disease. Br J Haematol. 2008; 141(1): 126-9.

PubMed Abstract | Publisher Full Text

56. Molokie R, Lavelle D, Gowhari M, et al:: Oral tetrahydrouridine and decitabine for non-cytotoxic epigenetic gene regulation in sickle cell disease: A randomized phase 1 study. PLoS Med. 2017; 14(9): e1002382 PubMed Abstract | Publisher Full Text | Free Full Text

57. Atweh GF, Sutton M, Nassif I, et al:: Sustained induction of fetal hemoglobin by pulse butyrate therapy in sickle cell disease. Blood. 1999; 93(6): 1790-7. PubMed Abstract | Publisher Full Text | Free Full Text

58. Hebbel RP, Vercellotti GM, Pace BS, et al:: The HDAC inhibitors trichostatin A and suberoylanilide hydroxamic acid exhibit multiple modalities of benefit for the vascular pathobiology of sickle transgenic mice. Blood. 2010; 115(12) 2483-90.

PubMed Abstract | Publisher Full Text | Free Full Tex

59. Ikuta T, Atweh G, Boosalis V, et al: Cellular and Molecular Effects of a Pulse Butyrate Regimen and New Inducers of Globin Gene Expression and Hematopoiesis. Ann N Y Acad Sci. 1998; 850: 87-99. PubMed Abstract | Publisher Full Text

60. Kutlar A, Ataga K, Reid M, et al: A phase 1/2 trial of HQK-1001, an oral fetal globin inducer, in sickle cell disease. Am J Hematol. 2012; 87(11): 1017-21. PubMed Abstract | Publisher Full Text | Free Full Text

61. Kutlar A, Reid ME, Inati A, et al:: A dose-escalation phase lla study of 2,2-dimethylbutyrate (HQK-1001), an oral fetal globin inducer, in sickle cell disease. Am J Hematol. 2013; 88(11): E255-E260.

PubMed Abstract | Publisher Full Text

62. Okam MM, Esrick EB, Mandell E, et al.: Phase 1/2 trial of vorinostat in patients 
with sickle cell disease who have not benefitted from hydroxyurea. Blood. 2015; 125(33): 3668-9.

PubMed Abstract | Publisher Full Text | Free Full Text

63. F Reid ME, El Beshlawy A, Inati A, et al.: A double-blind, placebo-controlled phase II study of the efficacy and safety of 2,2-dimethylbutyrate (HQK-1001), an oral fetal globin inducer, in sickle cell disease. Am J Hematol. 2014; 89(7): $709-13$

PubMed Abstract | Publisher Full Text | Faculty Opinions Recommendation

64. Shearstone JR, Golonzhka O, Chonkar A, et al.: Chemical Inhibition of Histone Deacetylases 1 and 2 Induces Fetal Hemoglobin through Activation of GATA2 PLoS One 2016: 11: e0153767.

PubMed Abstract | Publisher Full Text | Free Full Text

65. Rivers A, Vaitkus K, Ruiz MA, et al.: RN-1, a potent and selective lysine-specific demethylase 1 inhibitor, increases $\gamma$-globin expression, $F$ reticulocytes, and $F$ cells in a sickle cell disease mouse model. Exp Hematol. 2015; 43(7): 546-553. e3.

PubMed Abstract | Publisher Full Text | Free Full Text

66. Cui S, Lim KC, Shi L, et al:: The LSD1 inhibitor RN-1 induces fetal hemoglobin synthesis and reduces disease pathology in sickle cell mice. Blood. 2015; 126(3): 386-96. PubMed Abstract | Publisher Full Text | Free Full Text

67. F Rivers A, Vaitkus $\mathrm{K}$, Jagadeeswaran $\mathrm{R}$, et al: Oral administration of the LSD1 inhibitor ORY-3001 increases fetal hemoglobin in sickle cell mice and baboons. Exp Hematol. 2018; 67: 60-64.e2 PubMed Abstract | Publisher Full Text | Faculty Opinions Recommendation

68. F Meiler SE, Wade M, Kutlar F, et al.: Pomalidomide augments fetal hemoglobin production without the myelosuppressive effects of hydroxyurea in transgenic sickle cell mice. Blood. 2011; 118(4): 1109-12. PubMed Abstract | Publisher Full Text | Free Full Text | Faculty Opinions Recommendation

69. Kutlar A, Swerdlow PS, Meiler SE, et al.: Pomalidomide In Sickle Cell Disease: Phase I Study Of a Novel Anti-Switching Agent. Blood. 2013; 122(21): 777. Publisher Full Text

70. $\mathrm{F}$ Zhang $\mathrm{Y}$, Paikari A, Sumazin $\mathrm{P}$, et al.: Metformin induces FOXO3-dependen etal hemoglobin production in human primary erythroid cells. Blood. 2018; 132(3): 321-33.

PubMed Abstract | Publisher Full Text | Free Full Text |

Faculty Opinions Recommendation

71. Krishnamoorthy S, Pace B, Gupta D, et al.: Dimethyl fumarate increases fetal hemoglobin, provides heme detoxification, and corrects anemia in sickle cell disease. JCl Insight. 2017; 2(20): e96409.

PubMed Abstract | Publisher Full Text | Free Full Text

72. Dai $\mathrm{Y}, \mathrm{Chen} \mathrm{T}$, ljaz $\mathrm{H}$, et al:: SIRT1 activates the expression of fetal hemoglobin genes. Am J Hematol. 2017; 92(11): 1177-1186.

PubMed Abstract | Publisher Full Text | Free Full Text

73. Oksenberg D, Dufu K, Patel MP, et al.: GBT440 increases haemoglobin oxygen affinity, reduces sickling and prolongs RBC half-life in a murine model of sickle cell disease. Br J Haematol. 2016; 175(1): 141-53.

PubMed Abstract| Publisher Full Text

74. $\mathrm{F}$ Howard J, Hemmaway CJ, Telfer $\mathrm{P}$, et al:: A phase 1/2 ascending dose study and open-label extension study of voxelotor in patients with sickle cell disease. Blood 2019; 133(17): 1865-1875.

PubMed Abstract | Publisher Full Text | Free Full Text | Faculty Opinions Recommendation

75. F Dufu K, Patel M, Oksenberg D, et al.: GBT440 improves red blood cell deformability and reduces viscosity of sickle cell blood under deoxygenated conditions. Clin Hemorheol Microcirc. 2018; 70(1): 95-105. PubMed Abstract | Publisher Full Text | Free Full Text | Faculty Opinions Recommendation

76. Vichinsky E, Hoppe CC, Ataga KI, et al:: A Phase 3 Randomized Trial of Voxelotor in Sickle Cell Disease. N Engl J Med. 2019; 381(6): 509-519. PubMed Abstract | Publisher Full Text

77. Kato GJ, Lawrence MP, Mendelsohn LG, et al: Phase 1 Clinical Trial Of The Candidate Anti-Sickling Agent Aes-103 In Adults With Sickle Cell Anemia. Blood. 2013; 122: 1009 Publisher Full Text

78. Kalfa TA, Kuypers FA, Telen MJ, et al: Phase 1 Single (SAD) and Multiple Ascending Dose (MAD) Studies of the Safety, Tolerability, Pharmacokinetics (PK) and Pharmacodynamics (PD) of FT-4202, an Allosteric Activator of Pyruvate Kinase-R, in Healthy and Sickle Cell Disease Subjects. Blood. 2019; 134(Supplement_1): 616.

Publisher Full Tex

79. Belcher JD, Young M, Chen C, et al.: MP4CO, a pegylated hemoglobin saturated with carbon monoxide, is a modulator of $\mathrm{HO}-1$, inflammation, and vaso-occlusion in transgenic sickle mice. Blood. 2013; 122(15): 2757-64. PubMed Abstract | Publisher Full Text | Free Full Text

80. Abuchowski A: SANGUINATE (PEGylated Carboxyhemoglobin Bovine): Mechanism of Action and Clinical Update. Artif Organs. 2017; 41(4): 346-350. PubMed Abstract | Publisher Full Text

81. Keipert PE: Clinical Evaluation of MP4CO: A Phase 1b Escalating-Dose, Safety and Tolerability Study in Stable Adult Patients with Sickle Cell Disease. Adv
Exp Med Biol. 2016; 923: 23-29

PubMed Abstract | Publisher Full Tex

82. Misra $\mathrm{H}$, Bainbridge $\mathrm{J}$, Berryman $\mathrm{J}$, et al: A Phase lb open label, randomized, safety study of SANGUINATETM in patients with sickle cell anemia. Rev Bras Hematol Hemoter. 2017; 39(1): 20-27.

PubMed Abstract | Publisher Full Text | Free Full Text

83. Sunshine HR, Hofrichter J, Eaton WA: Requirement for therapeutic inhibition of sickle haemoglobin gelation. Nature. 1978; 275(5677): 238-40. PubMed Abstract | Publisher Full Text

84. Ataga $\mathrm{KI}$, Reid M, Ballas SK, et al:: Improvements in haemolysis and indicators of erythrocyte survival do not correlate with acute vaso-occlusive crises in patients with sickle cell disease: A phase III randomized, placebo-controlled, double-blind study of the Gardos channel blocker senicapoc (ICA-17043). Br J Haematol. 2011; 153(1): 92-104.

PubMed Abstract | Publisher Full Tex

85. Ataga KI, Smith WR, de Castro LM, et al.: Efficacy and safety of the Gardos channel blocker, senicapoc (ICA-17043), in patients with sickle cell anemia. Blood. 2008; 111(8): 3991-7.

PubMed Abstract | Publisher Full Text

86. Brousseau DC, Scott JP, Badaki-Makun O, et al:: A multicenter randomized controlled trial of intravenous magnesium for sickle cell pain crisis in children. Blood. 2015; 126(14): 1651-7.

PubMed Abstract | Publisher Full Text | Free Full Text

87. Goldman RD, Mounstephen W, Kirby-Allen M, et al.: Intravenous magnesium sulfate for vaso-occlusive episodes in sickle cell disease. Pediatrics. 2013; 132(6): e1634-41.

PubMed Abstract | Publisher Full Text

88. de Franceschi L, Bachir D, Galacteros F, et al.: Oral magnesium pidolate: Effects of long-term administration in patients with sickle cell disease. $\mathrm{Br} J$ Haematol. 2000; 108(2): 284-9.

PubMed Abstract | Publisher Full Text

89. Swift R, Abdulmalik O, Chen Q, et al:: SCD-101: A New Anti-Sickling Drug Reduces Pain and Fatigue and Improves Red Blood Cell Shape in Periphera Blood of Patients with Sickle Cell Disease. Blood. 2016; 128(22): 121. Publisher Full Text

90. F Niihara Y, Smith WR, Stark CW: A Phase 3 Trial of I-Glutamine in Sickle Cell Disease. N Engl J Med. 2018; 379(19): 1880.

PubMed Abstract | Publisher Full Text | Faculty Opinions Recommendation

91. Nur E, Brandjes DP, Teerlink $\mathrm{T}$, et al.: $\mathrm{N}$-acetylcysteine reduces oxidative stress in sickle cell patients. Ann Hematol. 2012; 91(7): 1097-105. PubMed Abstract | Publisher Full Text | Free Full Text

92. F Sins JWR, Fijnvandraat K, Rijneveld AW, et al:: Effect of $\mathrm{N}$-acetylcysteine on pain in daily life in patients with sickle cell disease: A randomised clinical trial. Br J Haematol. 2018; 182(3): 444-8.

PubMed Abstract | Publisher Full Text | Faculty Opinions Recommendation

93. Ataga KI, Kutlar A, Kanter J, et al:: Crizanlizumab for the Prevention of Pain Crises in Sickle Cell Disease. N Engl J Med. 2017; 376(5): 429-39. PubMed Abstract | Publisher Full Text | Free Full Text

94. Orringer EP, Casella JF, Ataga KI, et al:: Purified poloxamer 188 for treatment of acute vaso-occlusive crisis of sickle cell disease: A randomized controlled trial. JAMA. 2001; 286(17): 2099-106. PubMed Abstract | Publisher Full Text

95. https://www.prnewswire.com/news-releases/mast-therapeutics-reports-topline-results-from-phase-3-study-in-sickle-cell-disease-300331289.html

96. F Chang J, Patton JT, Sarkar A, et al:: GMI-1070, a novel pan-selectin antagonist, reverses acute vascular occlusions in sickle cell mice. Blood. 2010; 116(10): 1779-86

PubMed Abstract | Publisher Full Text | Free Full Text |

Faculty Opinions Recommendation

97. F Telen MJ, Wun T, McCavit TL, et al:: Randomized phase 2 study of GMI-1070 in SCD: Reduction in time to resolution of vaso-occlusive events and decreased opioid use. Blood. 2015; 125(17): 2656-64. PubMed Abstract | Publisher Full Text | Free Full Text | Faculty Opinions Recommendation

98. https://www.pfizer.com/news/press-release/press-release-detail/pfizer announces phase_3_top line results for rivipansel in patients with sickle_cell_disease_experiencing_a_vaso_occlusive_crisis

99. Matsui NM, Varki A, Embury SH: Heparin inhibits the flow adhesion of sickle red blood cells to P-selectin. Blood. 2002; 100(10): 3790-6. PubMed Abstract | Publisher Full Text

100. Embury SH, Matsui NM, Ramanujam S, et al:: The contribution of endothelial cell P-selectin to the microvascular flow of mouse sickle erythrocytes in vivo. Blood. 2004; 104(10): 3378-85. PubMed Abstract | Publisher Full Text

101. Qari MH, Aljaouni SK, Alardawi MS, et al: Reduction of Painful Vaso-occlusive Crisis of Sickle Cell Anaemia by Tinzaparin in a Double-blind Randomized Trial. Thromb Haemost. 2017; 98(02): 392-6. PubMed Abstract | Publisher Full Text

102. Telen MJ, Batchvarova M, Shan S, et al:: Sevuparin Binds to Multiple Adhesive Ligands and Reduces Sickle Red Blood Cell-induced Vaso-occlusion. Br J 
Haematol. 2016; 175: 935-48.

PubMed Abstract | Publisher Full Text

103. Biemond BJ, Tombak A, Kilinc Y, et al.: Efficacy and Safety of Sevuparin, a Novel Non-Anti-Coagulant Heparinoid, in Patients with Acute Painful Vaso-Occlusive Crisis; A Global, Multicenter Double-Blind, Randomized, Placebo-Controlled Phase 2 Trial (TVOC01). Blood. 2019; 134(supp 1): 614. Publisher Full Text

104. Jang JE, Hidalgo A, Frenette PS: Intravenous immunoglobulins modulate neutrophil activation and vascular injury through FcyRIII and SHP-1. Circ Res. 2012; 110(8): 1057-66.

PubMed Abstract | Publisher Full Text | Free Full Text

105. Manwani D, Chen G, Carullo V, et al:: Single-dose Intravenous Gammaglobulin Can Stabilize Neutrophil Mac-1 Activation in Sickle Cell Pain Crisis. Am J Hematol. 2015; 90(5): 381-5

PubMed Abstract | Publisher Full Text | Free Full Text

106. Griffin TC, McIntire D, Buchanan GR: High-dose intravenous methylprednisolone therapy for pain in children and adolescents with sickle cell disease. $N$ Engl $J$ Med. 1994; 330(11): 733-7.

PubMed Abstract | Publisher Full Text

107. Bernini JC, Rogers ZR, Sandler ES, et al:: Beneficial Effect of Intravenous Dexamethasone in Children With Mild to Moderately Severe Acute Chest Syndrome Complicating Sickle Cell Disease. Blood. 1998; 92(9): 3082-9. PubMed Abstract | Publisher Full Tex

108. F Leonard A, Godiwala N, Herrera N, et al:: Early Initiation of Inhaled Corticosteroids does not Decrease Acute Chest Syndrome Morbidity in Pediatric Patients with Sickle Cell Disease. Blood Cells Mol Dis. 2018; 71: 55-62. PubMed Abstract | Publisher Full Text | Faculty Opinions Recommendation

109. F Glassberg J, Minnitti C, Cromwell C, et al.: Inhaled Steroids Reduce Pain and sVCAM Levels in Individuals with Sickle Cell Disease: A Triple-blind, Randomized trial. Am J Hematol. 2017; 92: 622-31.

PubMed Abstract | Publisher Full Text | Free Full Text |

Faculty Opinions Recommendation

110. Wallace KL, Linden J: Adenosine A2A Receptors Induced on iNKT and NK Cells Reduce Pulmonary Inflammation and Injury in Mice with Sickle Cell Disease. Blood 2010; 116: 5010-20. PubMed Abstract | Publisher Full Text | Free Full Text

111. F Field JJ, Lin G, Okam MM, et al:: Sickle cell vaso-occlusion cause activation of iNKT cells that is decreased by the adenosine A2A receptor agonist regadenoson. Blood. 2013; 121(17): 3329-34. PubMed Abstract | Publisher Full Text | Free Full Text | Faculty Opinions Recommendation

112. Field JJ, Majerus E, Gordeuk VR, et al.: Randomized phase 2 trial of regadenoson for treatment of acute vaso-occlusive crises in sickle cell disease. Blood Adv. 2017; 1(20): 1645-9. PubMed Abstract | Publisher Full Text | Free Full Text

113. Field JJ, Majerus E, Ataga KI, et al.: NNKTT120, an anti-iNKT cell monoclonal antibody, produces rapid and sustained iNKT cell depletion in adults with sickle cell disease. PLoS One. 2017; 12(2): e0171067. PubMed Abstract | Publisher Full Text | Free Full Text

114. Hoppe C, Kuypers F, Larkin S, et al:: A pilot study of the short-term use of simvastatin in sickle cell disease: Effects on markers of vascular dysfunction. Br J Haematol. 2011; 153(5): 655-63. PubMed Abstract | Publisher Full Text | Free Full Text

115. Hoppe C, Jacob E, Styles L, et al:: Simvastatin reduces vaso-occlusive pain in sickle cell anaemia: A pilot efficacy trial. Br J Haematol. 2017; 177(4): 620-9. PubMed Abstract | Publisher Full Text | Free Full Text

116. Ataga $\mathrm{KI}$, Wichlan $\mathrm{D}$, Elsherif $\mathrm{L}$, et al:: A pilot study of the effect of atorvastatin on endothelial function and albuminuria in sickle cell disease. Am J Hematol. 2019; 94(11): E299-E301.

PubMed Abstract | Publisher Full Text

117. Daak AA, Ghebremeskel K, Hassan Z, et al:: Effect of omega-3 (n-3) fatty acid supplementation in patients with sickle cell anemia: Randomized, doubleblind, placebo-controlled trial. Am J Clin Nutr. 2013; 97(1): 37-44. PubMed Abstract | Publisher Full Text

118. F Daak AA, Dampier CD, Fuh B, et al.: Double-blind, randomized, multicente phase 2 study of SC411 in children with sickle cell disease (SCOT trial). Blood Adv. 2018; 2(15): 1969-79.

PubMed Abstract | Publisher Full Text | Free Full Text

Faculty Opinions Recommendation

119. Rees DC, Kilinc Y, Unal S, et al.: Double-Blind, Randomized Study of Canakinumab Treatment in Pediatric and Young Adult Patients with Sickle Cell Anemia. Blood. 2019; 134: 615 .

Publisher Full Text

120. Gavins FNE, Russell J, Senchenkova EL, et al.: Mechanisms of enhanced thrombus formation in cerebral microvessels of mice expressing hemoglobinS. Blood. 2011; 117(15): 4125-33. PubMed Abstract | Publisher Full Text | Free Full Text
121. Chantrathammachart $P$, Mackman N, Sparkenbaugh $E$, et al:: Tissue Factor Promotes Activation of Coagulation and Inflammation in a Mouse Model of Sickle Cell Disease. Blood. 2012; 120(3): 636-46. PubMed Abstract | Publisher Full Text | Free Full Text

122. Arumugam PI, Mullins ES, Shanmukhappa SK, et al.: Genetic diminution of circulating prothrombin ameliorates multiorgan pathologies in sickle cel disease mice. Blood. 2015; 126(15): 1844-55. PubMed Abstract | Publisher Full Text | Free Full Text

123. Ataga KI, Key NS: Hypercoagulability in Sickle Cell Disease: New Approaches to an Old Problem. Hematology Am Soc Hematol Educ Program. 2007; 2007 91-6.

PubMed Abstract | Publisher Full Text

124. Pakbaz Z, Wun T: Role of the Hemostatic System on Sickle Cell Disease Pathophysiology and Potential Therapeutics. Hematol Oncol Clin North Am. 2014; 28(2): 355-74 PubMed Abstract | Publisher Full Text | Free Full Text

125. Greenberg J, Ohene-Frempong K, Halus J, et al:: Trial of Low Doses of Aspirin as Prophylaxis in Sickle Cell Disease. J Pediatr. 1983; 102(5): 781-4. PubMed Abstract | Publisher Full Text

126. Osamo NO, Photiades DP, Famodu AA: Therapeutic effect of aspirin in sickle cell anaemia. Acta Haematol. 1981; 66(2): 102-7. PubMed Abstract | Publisher Full Text

127. Zago MA, Costa FF, Ismael SJ, et al.: Treatment of Sickle Cell Diseases With Aspirin. Acta Haematol. 1984; 72(1): 61-4. PubMed Abstract | Publisher Full Text

128. F Desai PC, Brittain JE, Jones SK, et al:: A Pilot Study of Eptifibatide for Treatment of Acute Pain Episodes in Sickle Cell Disease. Thromb Res. 2013; 132(3): $341-5$

PubMed Abstract | Publisher Full Text | Free Full Text | Faculty Opinions Recommendation

129. Cabannes R, Lonsdorfer J, Castaigne JP, et al:: Clinical and Biological DoubleBlind-Study of Ticlopidine in Preventive Treatment of Sickle-Cell Disease Crises. Agents Actions Suppl. 1984; 15: 199-212. PubMed Abstract

130. Heeney MM, Hoppe CC, Abboud MR, et al:: A Multinational Trial of Prasugrel for Sickle Cell Vaso-Occlusive Events. N Engl J Med. 2016; 374(7): 625-35. PubMed Abstract | Publisher Full Text

131. F Hsu LL, Sarnaik S, Williams S, et al.: A Dose-Ranging Study of Ticagrelor in Children Aged 3-17 Years With Sickle Cell Disease: A 2-part Phase 2 Study. Am $J$ Hematol. 2018; 93(12): 1493-500.

PubMed Abstract | Publisher Full Text | Free Full Text |

Faculty Opinions Recommendation

132. F Kanter J, Abboud MR, Kaya B, et al.: Ticagrelor Does Not Impact PatientReported Pain in Young Adults With Sickle Cell Disease: A Multicentre, Randomised Phase IIb Study. Br J Haematol. 2019; 184(2): 269-78. PubMed Abstract | Publisher Full Text | Free Full Text | Faculty Opinions Recommendation

133. Heeney MM, Abboud MR, Amilon C, et al.: Ticagrelor Versus Placebo for the Reduction of Vaso-Occlusive Crises in Pediatric Sickle Cell Disease: Rationale and Design of a Randomized, Double-Blind, Parallel-Group, Multicenter Phase 3 Study (HESTIA3). Contemp Clin Trials. 2019; 85: 105835.

PubMed Abstract | Publisher Full Text

134. Kato GJ, Steinberg MH, Gladwin MT: Intravascular Hemolysis and the Pathophysiology of Sickle Cell Disease. J Clin Invest. 2017; 127(3): 750-60. PubMed Abstract | Publisher Full Text | Free Full Text

135. Gladwin MT, Kato GJ, Weiner D, et al:: Nitric Oxide for Inhalation in the Acute Treatment of Sickle Cell Pain Crisis: A Randomized Controlled Trial. JAMA. 2011; 305(9): 893-902.

PubMed Abstract | Publisher Full Text | Free Full Text

136. Maitre B, Djibre M, Katsahian S, et al:: Inhaled Nitric Oxide for Acute Chest Syndrome in Adult Sickle Cell Patients: A Randomized Controlled Study. Intensive Care Med. 2015; 41(12): 2121-9. PubMed Abstract | Publisher Full Tex

137. F Morris CR, Kuypers FA, Lavrisha L, et al: A Randomized, Placebo-Controlled Trial of Arginine Therapy for the Treatment of Children With Sickle Cell Disease Hospitalized With Vaso-Occlusive Pain Episodes. Haematologica. 2013; 98(9): 1375-82.

PubMed Abstract | Publisher Full Text | Free Full Text | Faculty Opinions Recommendation

138. F Eleutério RMN, Nascimento FO, Araújo TG, et al:: Double-Blind Clinical Tria of Arginine Supplementation in the Treatment of Adult Patients With Sickle Cell Anaemia. Adv Hematol. 2019; 2019: 4397150.

PubMed Abstract | Publisher Full Text | Free Full Text | Faculty Opinions Recommendation

139. Machado RF, Barst RJ, Yovetich NA, et al:: Hospitalization for Pain in Patients With Sickle Cell Disease Treated With Sildenafil for Elevated TRV and Low Exercise Capacity. Blood. 2011; 118(4): 855-64. PubMed Abstract | Publisher Full Text | Free Full Text 


\section{Open Peer Review}

\section{Current Peer Review Status:}

\section{Editorial Note on the Review Process}

Faculty Reviews are review articles written by the prestigious Members of Faculty Opinions. The articles are commissioned and peer reviewed before publication to ensure that the final, published version is comprehensive and accessible. The reviewers who approved the final version are listed with their names and affiliations.

\section{The reviewers who approved this article are:}

\section{Version 1}

\section{Yogen Saunthararajah}

Department of Hematology and Oncology, Taussig Cancer Institute, Cleveland Clinic, Cleveland, $\mathrm{OH}$, USA

Competing Interests: YS has patents, owns equity in, and serves on the board of a company EpiDestiny that is developing drug therapy for sickle cell disease.

\section{Daniel E. Bauer}

${ }^{1}$ Division of Hematology/Oncology, Boston Children's Hospital, Boston, MA, USA

2 Department of Pediatric Oncology, Dana-Farber Cancer Institute, Boston, MA, USA

3 Department of Pediatrics, Harvard Medical School, Boston, MA, USA

Competing Interests: No competing interests were disclosed.

The benefits of publishing with F1000Research:

- Your article is published within days, with no editorial bias

- You can publish traditional articles, null/negative results, case reports, data notes and more

- The peer review process is transparent and collaborative

- Your article is indexed in PubMed after passing peer review

- Dedicated customer support at every stage

For pre-submission enquiries, contact research@f1000.com 